\title{
Knowledge, attitude and practice of traditional medicine- related adverse drug reaction (ADR) reporting among hospital pharmacists and traditional medicine practitioners in Thailand
}

Wiwan Worakunphanich ${ }^{1,2}$, Fonthip Thongsombutpanitch ${ }^{3}$, Sonthiporn Nilsonthi ${ }^{3}$, Sitaporn Youngkong 4,5 , Montarat Thavorncharoensap $4,5^{*}$

1 Doctor of Philosophy Program in Social, Economic, and Administrative Pharmacy, Department of Pharmacy, Faculty of Pharmacy, Mahidol University, Bangkok, Thailand.

2 Thai Traditional Medicine Research Institute, Department of Thai Traditional and Alternative Medicine, Ministry of Public Health, Nonthaburi, Thailand.

Doctor of Pharmacy program, Faculty of Pharmacy, Mahidol University, Bangkok, Thailand.

4 Health Technology Assessment Graduate Program, Mahidol University, Bangkok, Thailand.

5 Social and Administrative Pharmacy Excellence Research (SAPER) unit, Department of Pharmacy, Faculty of Pharmacy, Mahidol University, Bangkok, Thailand.

*Corresponding author:

Montarat Thavorncharoensap montarat.tha@mahidol.ac.th

\section{Keywords:}

Knowledge, Attitude, Adverse drug reaction, Traditional medicine, Pharmacovigilance

\begin{abstract}
To date, many studies were conducted to examine knowledge, attitude, and practice of adverse drug reaction (ADR) reporting among health care practitioners. However, a very limited number of the studies were specific to traditional medicine related-ADR reporting. In addition, studies among traditional medicine practitioners, who are key persons for safety monitoring of traditional medicine are scarce. This study aimed to evaluate knowledge, attitude, and practice of traditional medicine-related ADR reporting among hospital pharmacists and traditional medicine practitioners in Thailand. Furthermore, factors associated with ever reported traditional medicine-related ADRs were investigated. A cross-sectional study using mail questionnaire survey was conducted. Samples were hospital pharmacists and traditional medicine practitioners, who were currently working at the selected 205 hospitals throughout the countries. Overall response rate of the survey was 47.56\% (195/410). Of the total respondents, 107 (54.9\%) were pharmacists while $87(44.6 \%)$ were traditional medicine practitioner. We found that pharmacists had higher knowledge score than traditional medicine practitioners $(15.47+3.25 \mathrm{VS} 11.99+2.99, p$ $<0.001)$. Both pharmacists and traditional medicine practitioner had positive attitude towards ADR reporting. Both groups of practitioners agreed that ADRs reporting improved the safety of traditional medicine. Nevertheless, only one third of pharmacist and traditional medicine practitioner have ever reported traditional medicine related-ADRs (34.9\% VS 26.4\% $p=0.206$ ). Factors associated with ever reported ADR related to traditional medicines were knowledge, education, and duration of work experiences. Improving knowledge through training program was essential in promoting traditional medicine-related ADR reporting in Thailand.
\end{abstract}

\section{INTRODUCTION}

Safety is a fundamental principle in the provision and promotion of any health-care treatment including traditional medicine ${ }^{1}$. Given the worldwide growing use of traditional medicine, safety of such products has become a major public concern. Contrary to the common belief that traditional medicine is safe, a number of traditional medicinal products are associated with serious adverse events, for instance, hepatotoxicity events ${ }^{2}$, Stevens-Johnson syndrome, and anaphylactic shock ${ }^{3}$. In response to this safety concern, WHO has
Pharmaceutical Sciences Asia (C) 2021 by Faculty of Pharmacy, Mahidol University, Thailand is licensed under CCBY-NC-ND 4.0. To view a copy of this license, visit https:// www.creativecommons.org/ licenses/by-nc-nd/4.0/ 
established a guideline on safety monitoring of traditional medicines in pharmacovigilance system $^{4}$. Nevertheless, the capacity of reporting adverse events on traditional medicine is seriously hampered due to several factors including the inadequate reporting schemes 5 .

Currently, spontaneous reporting system is considered the most common method for safety monitoring of medical products including tradetional medicine. Nevertheless, underreporting is a major challenge of this method ${ }^{6,7}$. Systematic review among physicians, pharmacists, and nurses found that lack of know- ledge, awareness and attitude of both adverse drug reactions (ADRs) and $\mathrm{ADR}$ reporting were associated with the under-reporting ${ }^{8-11}$.

Underreporting of adverse events (AEs) related to traditional medicine is even more serious. In 2010, approximately 21,000 from over 4 million reports submitted to the Uppsala Monitoring Centre (UMC) were related to herbal or natural products $^{12}$. Challenges in safety monitoring of traditional medicine include the complexity of such products, the lack of knowledge regarding the products among health care providers, unawareness of physician/patient that such ADRs should be reported, and the physician's unawareness of the use of such products ${ }^{1,4,12,13}$. In response to these challenges, important recommendations by world health organization (WHO) were to expand the source of report by including traditional medicine providers and to provide training on the causality assessment to the providers ${ }^{4,12}$.

In Thailand, the use of traditional medicine was widely promoted by government. Similar to other countries, spontaneous report was the main method to identify and to monitor safety of traditional medicine. Thai Vigibase, maintained by Health Product Vigilance Center (HPVC), is the national database that collects spontaneous reports from all health products including traditional medicine. Nevertheless, reported related to traditional medicine was accounted for only $0.3 \%$ of all reports in Thai vigibase during 1999-2015.

Understanding knowledge, attitude, and current practices related ADR report among health care practitioners can help designing suitable interventions to solve the underreport problem. To date, almost all studies examining knowledge, attitude and experiences towards ADR reporting were conducted among medical doctor, pharmacists, and nurses ${ }^{8-11}$. Although, traditional medicine practitioner was recognized as an important source of traditional medicine-related ADR report, very limited studies were conducted among this group of practitioners ${ }^{14-16}$. In addition, almost all studies ${ }^{8-11}$ were not specifically focused on traditional medicinerelated ADR report, which involved specific challenges. Thus, this study aims to examine knowledge, attitude, and practice toward traditional medicine-related ADR report among hospital pharmacists and traditional medicine practitioners in Thailand. In addition, factors associated with ever reported traditional medicine-related ADRs were explored.

\section{MATERIALS AND METHODS}

\subsection{Study design}

A cross-sectional survey using selfadministered questionnaire was conducted among hospital pharmacists and traditional medicine providers in Thailand. According to the sample size formula ${ }^{17}$, the sample size required to estimate the proportion of ever reporting traditional medicinerelated $\mathrm{ADRs}$ of $50 \%$ at margin of error 0.15 , with type I error at 0.05 was 43 . To account for response rate about $20 \%$, the sample size was inflated to 205 each for pharmacists and traditional medicine practitioners.

Then, 205 hospitals were purposively selected from 12 health area and Bangkok. Specifically, hospitals that reported the highest value of traditional medicine prescription or the highest utilization of traditional medicine during the year 2016 and had traditional medicine practitioners working in the hospital were purposively selected (approximately 15 hospitals for each health area).

\subsection{Method and data collection tools}

The questionnaire consisted of 4 parts as follows:(1) General characteristics; (2) Knowledge, which consisted of 9 items related to ADRs (i.e. definition of ADRs/serious ADRS, types of ADRs required to report and when to report), 6 items related to ADR reporting form (i.e. mandatory information, how to obtain reported etc.), and 8 items related to ADR reporting process (i.e. who can report, where to submit the form, etc.); (3) Attitude toward traditional medicine and ADR reporting of traditional medicine, which comprise 4 items related to attitude towards safety of traditional medicine and 10 items related to attitude towards ADR reporting; and (4) practice of traditional medicine-related ADR reporting, which comprises 4 items (i.e. have you ever advised/asked patients about traditional medicine-related ADRs, and have you ever encountered/reported traditional medicine-related ADRs) 
Questionnaires was distributed by postal mail to the head of pharmacy and the head of Thai traditional medicine section during October to December 2017. A cover letter explaining the purpose and method of the survey along with a reply-paid return envelope were provided. The respondents were asked to return the questionnaire within 3 weeks. Reminders were then sent by mail after 3 weeks to the non-response samples. The study was conducted after final approval from the Institutional Review Board of Mahidol University, Faculty of Dentistry/Faculty of Pharmacy (COE.No. MU-DT/PY-IRB 2017/042.0410).

\subsection{Data analysis}

Total knowledge score related to ADRs and ADR reporting was calculated. Total score ranges from 0 to 23 with the highest score represents higher knowledge. Comparison of knowledge, attitude and experiences between pharmacists and traditional medicine practitioners was analyzed using either T-test (or Mann-Whitney) for continuous variables or Chis-quare for categorical variables. Logistic regression was employed to examine factors affecting traditional medicine-related ADR reporting. Dependent variable was ever reported traditional medicine related ADR (yes/no). All analyses were performed using SPSS statistical software version 20. A $p$-value < 0.05 was considered to be statistically significant.

\section{RESULTS}

\subsection{Characteristics of respondents}

Of 410 questionnaires distributed, 195 were returned, resulting in the response rate of 195 (47.56\%). Of the total respondents, 107 (54.9\%) were pharmacists while $87(44.6 \%)$ were traditional medicine practitioner and $1(0.5 \%)$ was both pharmacists and traditional medicine practitioner. One hundred and fifty-one participants (77.4\%) were female. The mean age of the respondents was 36.72 \pm 9.11 years. A majority of the respondents $(76.4 \%)$ graduated with bachelor's degree or below (Table 1).

Table 1. Characteristics of the respondents.

\begin{tabular}{lr}
\hline & $\mathbf{n}(\mathbf{\%})$ \\
\hline Gender & $151(77.4)$ \\
Female & $44(22.6)$ \\
Male & \\
Education level & $149(76.4)$ \\
$\quad$ Bachelor's degree or below & $46(23.6)$ \\
Higher than Bachelor's degree & $107(54.9)$ \\
Position & $87(44.6)$ \\
$\quad$ Pharmacist & $1(0.5)$ \\
Traditional medicine practitioners & \\
Pharmacist and traditional medicine & \\
practitioners & $99(51.8)$ \\
Working experience & $71(37.2)$ \\
$\leq 10$ years & $21(11.0)$ \\
11 - 20 years & \\
\hline
\end{tabular}

\subsection{Knowledge towards ADRs and ADR reporting}

Table 2 presents knowledge related to ADR and ADR reporting among pharmacists and traditional medicine practitioners. It was found that more than half of pharmacists and traditional medicine practitioners did not know the timeline required to report each type of ADR nor definition of serious ADRs. In addition, more than half of traditional medicine practitioner did not know the causality assessment category, characteristics of ADR reporting form for each type of ADR monitoring (i.e. spontaneous report, intensive monitoring) and type of pharmaceutical product (i.e. western medicine, traditional medicine), and where to submit the ADR report form. When compared between pharmacists and traditional medicine practitioners, it was found that pharmacists had significant higher knowledge in 14 out of 23 items. The average knowledge's score of pharmacists was significantly higher than that of traditional medicine practitioners $(15.47 \pm 3.25$ vs 11.99 $\pm 2.99 ; p<0.001$ ), as shown in Table 3 .

\subsection{Attitude towards traditional medicine and traditional medicine-related ADR reporting}

Attitude towards traditional medicine and traditional medicine-related ADR reporting. 
Table 2. Knowledge towards ADRs and ADR reporting process.

\begin{tabular}{|c|c|c|c|c|c|}
\hline & \multirow[t]{2}{*}{ Questions } & \multirow{2}{*}{$\begin{array}{l}\text { Correct } \\
\text { answer }\end{array}$} & \multicolumn{2}{|c|}{ Correct answers (\%) } & \multirow[t]{2}{*}{$p$ - value +} \\
\hline & & & Pharmacists & $\begin{array}{c}\text { Traditional } \\
\text { medicine } \\
\text { practitioners }\end{array}$ & \\
\hline 1. & $\begin{array}{l}\text { ADRs that resulted in pharmacological } \\
\text { treatment are classified as serious ADRs. }\end{array}$ & No & $57(53.3)$ & $32(36.8)$ & $0.022 *$ \\
\hline 2. & $\begin{array}{l}\text { Mild ADRs resulted from traditional } \\
\text { medicine such as diarrhea should not be } \\
\text { reported. }\end{array}$ & No & $92(86.0)$ & $71(81.6)$ & 0.408 \\
\hline 3. & Traditional medicine can cause serious ADR. & Yes & $103(96.3)$ & $67(77.0)$ & $<0.001 *$ \\
\hline 4. & Side effects were also classified as AEs. & Yes & $89(83.2)$ & $59(67.8)$ & $0.012 *$ \\
\hline 5. & $\begin{array}{l}\text { Adverse event is an injury that occurs } \\
\text { during the use of drug but does not } \\
\text { necessarily casually related to the drug. }\end{array}$ & Yes & $64(59.8)$ & $40(46.0)$ & 0.055 \\
\hline 6. & $\begin{array}{l}\text { Serious ADRs were ADRs that resulted in } \\
\text { death or life-threatening or permanent } \\
\text { disability or prolongation of hospitalization } \\
\text { or required pharmacological treatment, or } \\
\text { birth defect (teratogenicity effect) }\end{array}$ & No & $13(12.1)$ & $15(17.2)$ & 0.316 \\
\hline 7. & $\begin{array}{l}\text { ADRs resulted from overdose must be } \\
\text { reported. }\end{array}$ & No & $69(64.5)$ & $18(20.7)$ & $<0.001 *$ \\
\hline 8. & $\begin{array}{l}\text { All types of ADRs must be reported within } 7 \\
\text { days. }\end{array}$ & No & $41(38.3)$ & $19(21.8)$ & $0.014^{*}$ \\
\hline 9. & $\begin{array}{l}\text { Traditional medicine-related ADRs that } \\
\text { resulted in hospitalization must be reported } \\
\text { within } 24 \text { hours. }\end{array}$ & Yes & $31(29.0)$ & $14(16.4)$ & $0.035^{*}$ \\
\hline 10. & $\begin{array}{l}\text { ADR reporting form of traditional medicine } \\
\text { do not require information on ADR severity, } \\
\text { dose and administration. }\end{array}$ & No & $57(53.3)$ & $54(62.1)$ & 0.218 \\
\hline 11. & $\begin{array}{l}\text { The same ADR reporting form was used for } \\
\text { both intensive monitoring program and } \\
\text { spontaneous reporting. }\end{array}$ & Yes & $67(62.6)$ & $18(20.7)$ & $<0.001 *$ \\
\hline 12. & $\begin{array}{l}\text { Causality in ADR reporting form consists of } \\
3 \text { levels as follow: certain, probable and } \\
\text { unlikely. }\end{array}$ & No & $78(72.9)$ & $20(23.0)$ & $<0.001 *$ \\
\hline 13. & $\begin{array}{l}\text { ADR reporting form can be downloaded } \\
\text { from website. }\end{array}$ & Yes & $94(87.9)$ & $67(77.0)$ & $0.046^{*}$ \\
\hline 14. & $\begin{array}{l}\text { Different ADR reporting form was used for } \\
\text { western and traditional medicine because of } \\
\text { the difference in causality assessment. }\end{array}$ & No & $63(58.9)$ & $28(32.2)$ & $<0.001 *$ \\
\hline 15. & $\begin{array}{l}\text { Mandatory information in ADR reporting } \\
\text { form are patient information, source of } \\
\text { report, ADR description and suspected } \\
\text { medication. }\end{array}$ & Yes & 97 (90.7) & $78(89.7)$ & 0.816 \\
\hline 16. & $\begin{array}{l}\text { Only ADRs related to western medicine } \\
\text { must be reported. }\end{array}$ & No & $104(97.2)$ & $82(94.3)$ & 0.305 \\
\hline 17. & Consumers could also report ADRs. & Yes & $60(56.1)$ & $58(66.7)$ & 0.133 \\
\hline 18. & $\begin{array}{l}\text { Only physician is responsible for ADRs } \\
\text { assessment. }\end{array}$ & No & $100(93.5)$ & $75(86.2)$ & 0.091 \\
\hline 19. & $\begin{array}{l}\text { Only pharmacist is responsible for ADR } \\
\text { reporting. }\end{array}$ & No & $92(86.0)$ & $70(80.5)$ & 0.303 \\
\hline 20. & $\begin{array}{l}\text { ADR reports could be submitted to Thai } \\
\text { FDA via post, fax, e-mail and website. }\end{array}$ & Yes & 97 (90.7) & $69(79.3)$ & $0.025^{*}$ \\
\hline
\end{tabular}


Table 2. Knowledge towards ADRs and ADR reporting process. (cont.)

\begin{tabular}{|c|c|c|c|c|c|}
\hline & \multirow[t]{2}{*}{ Questions } & \multirow{2}{*}{$\begin{array}{l}\text { Correct } \\
\text { answer }\end{array}$} & \multicolumn{2}{|c|}{ Correct answers (\%) } & \multirow[t]{2}{*}{$p$ - value +} \\
\hline & & & Pharmacists & $\begin{array}{l}\text { Traditional } \\
\text { medicine } \\
\text { practitioners }\end{array}$ & \\
\hline 21. & $\begin{array}{l}\text { Training on ADR report is not required for } \\
\text { ADR reporter. }\end{array}$ & Yes & $51(47.7)$ & $31(35.6)$ & 0.092 \\
\hline 22. & $\begin{array}{l}\text { ADR reports from provincial hospitals must } \\
\text { be submitted to the Provincial Health Office. }\end{array}$ & No & $85(79.4)$ & 24 (27.6) & $<0.001 *$ \\
\hline 23. & $\begin{array}{l}\text { Traditional medicine-related ADR reports } \\
\text { must be submitted to the Department of Thai } \\
\text { traditional and alternative medicine. }\end{array}$ & No & $51(47.7)$ & $34(39.1)$ & 0.231 \\
\hline
\end{tabular}

+Chi-square, * Significant

Table 3. Comparison of knowledge score between pharmacists and traditional medicine practitioners.

\begin{tabular}{llc}
\hline & Mean \pm SD & $p-$ value $^{+}$ \\
\hline Pharmacists $(\mathrm{n}=107)$ & $15.47 \pm 3.25$ & $<0.001^{*}$ \\
Traditional medicine practitioners $(\mathrm{n}=87)$ & $11.99 \pm 2.99$ & \\
\hline
\end{tabular}

+ Mann-Whitney U, *Significant (score ranged from 0-23, with the highest score represent higher knowledge)

of pharmacists and traditional medicine practitioners were shown in Table 4.

For attitude towards traditional medicine, traditional medicine practitioners had more positive attitude towards efficacy and safety of traditional medicine than pharmacist. Traditional medicine practitioners were more likely than pharmacists to believe that traditional medicine was as effective as western medicine (78.2\% VS $54.7 \%, p=0.003)$. On the other hand, traditional medicine practitioners were more likely than pharmacists to believe that traditional medicine caused less $(89.7 \%$ vs $35.2 \% ; p<0.001)$ and milder side effects $(65.1 \%$ vs $19.8 \% ; p<0.001)$, when compared to western medicine.

In terms of attitude towards traditional medicine-related ADR reporting, both pharmacists and traditional medicine practitioners agreed that traditional medicine-related ADR reporting was important and that it could improve the safety of traditional medicine. For the responsibility of traditional medicine-related ADR reporting, 42.5\% of pharmacists agreed that traditional medicine related-ADR reporting should be the responsibility of pharmacists. In contrast, more than half (55.8\%) of traditional medicine practitioners believed that it should be the responsibility of traditional medicine practitioners.

\subsection{Practice of traditional medicine-related ADR reporting}

As shown in Table 5, traditional medicine practitioners were more likely to report that they had ever advised or asked patients about traditional medicine-related ADRs. Approximately $50 \%$ of both groups have encountered traditional medicinerelated ADRs. Only one third of the participants (34.9\% of pharmacists VS $26.4 \%$ of traditional medicine practitioners, $p=0.206$ ) have ever reported ADRs related to traditional medicine. The common reasons for non-reporting ADR were that ADRs could not be detected and that the encountered ADRs were non-serious.

\subsection{Factors associated with ever reported traditional medicine-related ADRs}

According to the univariate analysis, gender, age, type of profession (i.e. traditional medicine practitioners, pharmacists), and attitude towards traditional medicine/ traditional medicinerelated ADR reporting were not associated with ever reported traditional medicine-related ADRs. On the other hand, education, duration of work experiences, and knowledge were found to be associated with ever reported traditional medicinerelated ADRs. After included these variables into the multiple logistic regression model, we found that all of them were associated with ever reported ADR related to traditional medicine (Table 6). For every 1-point increase in knowledge score, the probability of ever reported ADR will increase approximately 1.2 times $(\mathrm{OR}=1.166 ; p=0.002)$. Respondents who has been working for $11-20$ years were about 2.4 time more likely to have 
ever reported ADR than those who had less than 10 years of work experience $(\mathrm{OR}=2.418 ; p=0.009)$. Furthermore, respondents who had higher than bachelor's degree were about 2.6 times $(\mathrm{OR}=2.562$; $p=0.007$ ) more likely to have ever reported ADRs than who graduated with bachelor's degree or below

Table 4. Attitude towards traditional medicine and ADR reporting of pharmacists and traditional medicine practitioners.

\begin{tabular}{|c|c|c|c|c|c|c|}
\hline & & & & n (\%) & & \\
\hline & Statements & HCPs & Agree & Neutral & Disagree & $p$ - value ${ }^{+}$ \\
\hline 1. & Traditional medicine is less & Pharmacists & $26(24.5)$ & $22(20.8)$ & $58(54.7)$ & $0.003^{*}$ \\
\hline & $\begin{array}{l}\text { effective than western } \\
\text { medicines. }\end{array}$ & $\begin{array}{l}\text { Traditional medicine } \\
\text { practitioners }\end{array}$ & $12(13.8)$ & $7(8.0)$ & $68(78.2)$ & \\
\hline 2. & Traditional medicine causes & Pharmacists & $37(35.2)$ & $17(16.2)$ & $51(48.6)$ & $<0.001 *$ \\
\hline & $\begin{array}{l}\text { less side effect than western } \\
\text { medicine }\end{array}$ & $\begin{array}{l}\text { Traditional medicine } \\
\text { practitioners }\end{array}$ & 78(89.7) & $3(3.4)$ & $6(6.9)$ & \\
\hline 3. & ADRs associated with & Pharmacists & $21(19.8)$ & $18(17.0)$ & $67(63.2)$ & $<0.001 *$ \\
\hline & $\begin{array}{l}\text { traditional medicine are mild } \\
\text { as it has been used for long } \\
\text { time. }\end{array}$ & $\begin{array}{l}\text { Traditional medicine } \\
\text { practitioners }\end{array}$ & $56(65.1)$ & $9(10.5)$ & $21(24.4)$ & \\
\hline 4. & The use of western medicine & Pharmacists & $32(30.5)$ & $29(27.6)$ & 44(41.9) & 0.197 \\
\hline & $\begin{array}{l}\text { together with traditional } \\
\text { medicine increases the risk of } \\
\text { ADR. }\end{array}$ & $\begin{array}{l}\text { Traditional medicine } \\
\text { practitioners }\end{array}$ & $34(40.0)$ & $15(17.6)$ & $36(42.4)$ & \\
\hline 5. & The use of traditional & Pharmacists & $46(43.4)$ & $16(15.1)$ & $44(41.5)$ & 0.057 \\
\hline & $\begin{array}{l}\text { medicine among patients with } \\
\text { chronic diseases increases the } \\
\text { risk of ADR. }\end{array}$ & $\begin{array}{l}\text { Traditional medicine } \\
\text { practitioners }\end{array}$ & $28(32.2)$ & $8(9.2)$ & $51(58.6)$ & \\
\hline 6. & Reporting ADR related to & Pharmacists & $7(6.7)$ & $16(15.2)$ & $82(78.1)$ & 0.722 \\
\hline & $\begin{array}{l}\text { traditional medicine decreases } \\
\text { the trust of traditional } \\
\text { medicine. }\end{array}$ & $\begin{array}{l}\text { Traditional medicine } \\
\text { practitioners }\end{array}$ & $7(8.0)$ & $10(11.5)$ & $70(80.5)$ & \\
\hline 7. & Compared to western & Pharmacists & $9(8.7)$ & $38(36.5)$ & $57(54.8)$ & 0.416 \\
\hline & $\begin{array}{l}\text { medicine, process of } \\
\text { traditional medicine -related } \\
\text { ADR reporting is more } \\
\text { complicated. }\end{array}$ & $\begin{array}{l}\text { Traditional medicine } \\
\text { practitioners }\end{array}$ & $10(11.6)$ & $24(27.9)$ & $52(60.5)$ & \\
\hline 8. & Reporting ADRs related to & Pharmacists & $6(5.7)$ & $30(28.6)$ & $69(65.7)$ & $0.028^{*}$ \\
\hline & $\begin{array}{l}\text { traditional medicine increases } \\
\text { the workload. }\end{array}$ & $\begin{array}{l}\text { Traditional medicine } \\
\text { practitioners }\end{array}$ & $3(3.4)$ & $12(13.8)$ & $72(82.8)$ & \\
\hline 9. & Reporting ADRs related to & Pharmacists & $45(42.5)$ & $18(17.0)$ & $43(40.6)$ & $0.009 *$ \\
\hline & $\begin{array}{l}\text { traditional medicine is the } \\
\text { responsibility of pharmacist. }\end{array}$ & $\begin{array}{l}\text { Traditional medicine } \\
\text { practitioners }\end{array}$ & $22(25.6)$ & 10(11.6) & $54(62.8)$ & \\
\hline 10. & Assessment of ADRs related & Pharmacists & $33(31.1)$ & $27(25.5)$ & $46(43.4)$ & $0.002 *$ \\
\hline & $\begin{array}{l}\text { to traditional medicine is the } \\
\text { responsibility of traditional } \\
\text { medicine practitioners }\end{array}$ & $\begin{array}{l}\text { Traditional medicine } \\
\text { practitioners }\end{array}$ & $48(55.8)$ & $11(12.8)$ & $27(31.4)$ & \\
\hline 11. & Compared to western & Pharmacists & $42(40.0)$ & $31(29.5)$ & $32(30.5)$ & $0.026^{*}$ \\
\hline & $\begin{array}{l}\text { medicine, assessment of } \\
\text { ADRs related to traditional } \\
\text { medicine is more difficult. }\end{array}$ & $\begin{array}{l}\text { Traditional medicine } \\
\text { practitioners }\end{array}$ & $21(24.7)$ & $23(27.1)$ & $41(48.2)$ & \\
\hline 12. & $A D R$ reporting form require & Pharmacists & $49(46.7)$ & $39(37.1)$ & $17(16.2)$ & $0.020^{*}$ \\
\hline & detailed information. & $\begin{array}{l}\text { Traditional medicine } \\
\text { practitioners }\end{array}$ & $57(66.3)$ & 18(20.9) & $11(12.8)$ & \\
\hline 13. & ADR monitoring of & Pharmacists & $1(0.9)$ & $2(1.9)$ & 103(97.2) & 0.246 \\
\hline & $\begin{array}{l}\text { traditional medicine is } \\
\text { unnecessary as the product is } \\
\text { safe. }\end{array}$ & $\begin{array}{l}\text { Traditional medicine } \\
\text { practitioners }\end{array}$ & $4(4.6)$ & $3(3.4)$ & $80(92.0)$ & \\
\hline 14. & ADR reporting improves the & Pharmacists & 104(98.1) & $1(0.9)$ & $1(0.9)$ & 0.280 \\
\hline & $\begin{array}{l}\text { safety of the use of traditional } \\
\text { medicine. }\end{array}$ & $\begin{array}{l}\text { Traditional medicine } \\
\text { practitioners }\end{array}$ & $80(93.0)$ & $3(3.5)$ & $3(3.5)$ & \\
\hline
\end{tabular}

$\mathrm{HCPs}=$ Health care providers, + Chi-square 
Table 5. Practice towards traditional medicine-related ADR reporting among pharmacist and traditional medicine practitioners.

\begin{tabular}{|c|c|c|c|}
\hline & $\begin{array}{l}\text { Health care } \\
\text { practitioner }\end{array}$ & Yes $(\%)$ & $p$ - value ${ }^{+}$ \\
\hline $\begin{array}{l}\text { 1. Have you ever advised patients about traditional medicine- } \\
\text { related ADRs? }\end{array}$ & $\begin{array}{l}\text { Pharmacists } \\
\text { Traditional medicine } \\
\text { practitioners }\end{array}$ & $\begin{array}{ll}74 & (69.8) \\
85 & (97.7)\end{array}$ & $<0.001^{*}$ \\
\hline $\begin{array}{l}\text { 2. Have you ever asked patients about traditional medicine- } \\
\text { related ADRs? }\end{array}$ & $\begin{array}{l}\text { Pharmacists } \\
\text { Traditional medicine } \\
\text { practitioners }\end{array}$ & $\begin{array}{l}80(75.5) \\
87(100.0)\end{array}$ & $<0.001^{*}$ \\
\hline $\begin{array}{l}\text { 3. Have you ever encountered traditional medicine-related } \\
\text { ADRs? }\end{array}$ & $\begin{array}{l}\text { Pharmacists } \\
\text { Traditional medicine } \\
\text { practitioners }\end{array}$ & $\begin{array}{l}57(53.8) \\
40(46.0)\end{array}$ & 0.281 \\
\hline 4. Have you ever reported traditional medicine-related ADRs? & $\begin{array}{l}\text { Pharmacists } \\
\text { Traditional medicine } \\
\text { practitioners }\end{array}$ & $\begin{array}{l}37(34.9) \\
23(26.4)\end{array}$ & 0.206 \\
\hline
\end{tabular}

+ Chi-square, *significant

Table 6. Factors associated with ever reported traditional medicine-related ADRs.

\begin{tabular}{lcccc}
\hline \multicolumn{1}{c}{ Factors } & $\boldsymbol{\beta}$ & SE $(\boldsymbol{\beta})$ & $\boldsymbol{p}$ - value $^{+}$ & OR \\
\hline Constant & -3.189 & 0.803 & $<0.001$ & 0.041 \\
Total score of knowledge & 0.136 & 0.054 & 0.012 & 1.145 \\
Duration of work experience & & & & - \\
$\quad<$ 10 years (Reference) & - & - & - & 2.265 \\
$\quad$ 11-20 years & 0.818 & 0.350 & 0.019 & 1.210 \\
$\quad$ 20 years & 0.190 & 0.559 & 0.733 & - \\
$\quad$ Education level & & & & - \\
$\quad$ Bachelor's degree or below (Reference) & - & - & 0.187 & 1.675 \\
\hline
\end{tabular}

Cox\& Snell R Square 0.094, Nagelkerke R Square 0.132

\section{DISCUSSION}

Similar to previous study ${ }^{16}$, we found that pharmacists had higher knowledge related to $\mathrm{ADRs}$ and $\mathrm{ADR}$ reporting form/ process than traditional medicine practitioners. This could be explained by the fact that pharmacists were obligated to monitor and report ADR and that knowledge of pharmacovigilance were included in the pharmacy curriculum. On the other hand, very few traditional medicine practitioners have been trained on ADR reporting process ${ }^{14}$.

Consistent with previous studies ${ }^{8-10}$, we found that knowledge was an important predictor of ADR reporting experience. Specifically, we found that those with high knowledge on ADR/ADR reporting process were more likely to have ever reported traditional medicine-related ADRs. According to the previous systematic review ${ }^{10}$, health care providers felt that they had not received adequate training about ADR report. As traditional medicine practitioners were key persons in pharmacovigilance of such products, this finding clearly supports the need for ADR report training among traditional medicine practitioners. In addition, such training program is also needed for pharmacists to reinforce the knowledge and positive attitude toward ADRs reporting.

In terms of knowledge related to $\mathrm{ADR}$ and ADR reporting, most of our respondents, especially traditional medicine practitioner, had poor knowledge on the definition of serious ADRs and timeline to report serious ADRs. In addition, lack of knowledge regarding the channel/place to submit ADR report and causality assessment level were also common among traditional medicine practitioners. According to $\mathrm{WHO}^{18}$, doubt regarding causal role of drug may lead to the reluctant to report ADRs. Consistent with the WHO recommendation ${ }^{4}$, our finding confirms that training should also focus on causality assessment. Similar to previous studies ${ }^{14,15}$, knowledge on the ADR reporting form among traditional medicine practitioners were also limited. In summary, our study suggested that the content of training program should cover the following knowledge; definition of serious ADRs, timeline to report 
serious ADRs, characteristics of ADR reporting form, place to submit ADR report, and causality assessment.

In terms of attitude towards traditional medicine, similar to previous studies ${ }^{14,15}$, traditional medicine practitioners were more likely to have positive attitude towards safety and efficacy of such products. With respect to attitude towards ADR reporting, both of pharmacists and traditional medicine practitioners had positive attitude towards traditional medicine related ADR reporting. Less than half of pharmacists (42.5\%) agreed that traditional medicine-related ADRs reporting should be the responsibility of pharmacists. On the other hand, approximately $56 \%$ of traditional medicines agreed that traditional medicine-related ADR reporting should be the responsibility of them. As the result, awareness of responsibility in traditional medicine-related ADR reporting should be raised among both pharmacists and traditional medicine practitioners. In addition, multidisciplinary team that involve pharmacist and traditional medicine practitioner are needed to be established for effective safety monitoring of traditional medicine.

Consistent with the previous studies ${ }^{8,10}$, proportions of both traditional medicine practitioners and pharmacists, who have ever reported ADRs related to traditional medicine were low. Nevertheless, they were higher than those of other studies, which found that only $0.8 \%-2 \% 14,15$ of traditional medicine practitioners have ever reported ADR. This can be explained by the fact that our samples were selected from the hospitals with high utilization rate of traditional medicine. As the result, they might represent practitioners, who were more familiar with traditional medicine and ADR related to traditional medicine. Similar to previous studies, common reasons for not reporting ADRs from our participants were that they rarely encountered with $\mathrm{ADRs}{ }^{15}$, and that ADR was not serious ${ }^{11,15}$. Consistent with the previous studies ${ }^{19,20}$, proportion of both traditional medicine practitioners and pharmacists in our study, who have ever encountered with ADRs related to traditional medicine was low. This could be due to the fact that several traditional medicine products were available for self-medication so that health care providers were unaware of the use of such products by the patients and that patients were more likely to just discontinue the use when experiencing ADRs without reporting it to the health care professional ${ }^{12,21}$. To promote the safety monitoring of such products, facilitating patient-report should be further encouraged ${ }^{4}$.
Although the proportion of pharmacists and traditional medicine practitioners, who have ever reported ADR was similar higher proportion of traditional medicine practitioners have ever advised and asked patients about ADRs related to traditional medicine. This could be explained by the fact that most of traditional medicine were prescribed by traditional medicine practitioners. This finding supports the recommendation that active involvement of traditional medicine practitioners in safety monitoring of traditional medicine were essential ${ }^{4}$.

Our study also identified that education level and duration of work experience were associated with ever reported traditional medicine-related ADR. Based on our findings, training program should be targeted to those whose working experiences were less than ten years and those with bachelor degree or lower. Nevertheless, training should also be expanded to other groups as well to maintain knowledge and re-enforced positive attitude towards ADR reporting.

Although our study is the first study examining knowledge, attitude, and experience related to traditional medicine-related ADR reporting in Thailand, which includes both pharmacists and traditional medicine practitioners it is not without limitation. First, this study relies on self-reported especially for the experiences in ADR reporting. Second, participants in this study were selected from hospitals that reported high utilization of traditional medicine so generalizability to participants from different settings should be made with caution.

\section{CONCLUSIONS}

Both pharmacists and traditional medicine practitioners had positive attitude towards traditional medicine- related ADR reporting. Nevertheless, pharmacists tend to possess more knowledge related to ADRs and ADRs reporting process than traditional medicine practitioners. Limited knowledge in terms of definition of serious ADRs and timeline of reporting serious ADRs was identified in both groups of practitioners. However, lack of knowledge on causality assessment, place to submit the report, and reporting form were more likely to be found among traditional medicine practitioners. It should be noted that proportion of participants who have ever reported traditional medicine-related ADRs was low (approximately 30\%). As knowledge was an important determinant of ever reported 
ADR related to traditional medicine, improving knowledge through training program was essential in promoting $\mathrm{ADR}$ reporting of traditional medicine in Thailand. Such training program should emphasize on definition of serious ADRs, timeline of reporting each type of ADRs, causality assessment, as well as ADR reporting form and place to submit ADR report.

\section{ACKNOWLEDGEMENT}

The authors would like to thank all hospital pharmacists and traditional medicine practitioners for their active participation and cooperation in responding to the questionnaire. In addition, the authors would like to acknowledge the financial support from Faculty of Pharmacy, Mahidol University.

\section{Conflict of interest}

All authors have no conflicts of interest to declare.

\section{Funding}

None to declare.

\section{Ethics approval}

Ethical approval for the study was conducted after final approval from the Institutional Review Board of Mahidol University, Faculty of Dentistry /Faculty of Pharmacy (COE.No. MU-DT/PY-IRB 2017/ 042.0410).

\section{Article info:}

Received April 19, 2020

Received in revised form April 19, 2020

Accepted October 5, 2020

\section{REFERENCES}

1. World Health Organization. WHO traditional medicine strategy: 2014-2023. Genava: WHO; 2013:1-78.

2. Bunchorntavakul C, Reddy KR. Review article: herbal and dietary supplement hepatotoxicity. Aliment Pharmacol Ther. 2013 Jan;37(1):3-17.

3. Saokaew S, Suwankesawong W, Permsuwan U, Chaiyakunapruk N. Safety of Herbal Products in Thailand An Analysis of Reports in the Thai Health Product Vigilance Center Database from 2000 to 2008. Drug Saf. 2011;34:339-50.

4. World Health Organization. WHO guidelines on safety monitoring of herbal medicines in pharmacovigilance systems. Geneva: WHO; 2004

5. Hazell L, Shakir SA. Under-reporting of adverse drug reactions : a systematic review. Drug Saf. 2006;29(5):385-96.

6. Hazell L, Shakir SAW. Under reporting of adverse drug reactions: a systematic review. Drug Saf. 2006;29:385-96.

7. World Health Organization. The pharmacovigilance system for traditional medicine in Thailand. WHO; 2017.

8. Bhagavathula AS, Elnour AA, Jamshed SQ, Shehab A. Health Professionals' Knowledge, Attitudes and Practices about Pharmacovigilance in India: A Systematic Review and Meta-Analysis. PLoS One. 2016;11(3):e0152221.

9. Hazell L, Shakir SA. Under-reporting of adverse drug reactions: a systematic review. Drug Saf. 2006;29(5):385-96.

10. Rabiu A, Simbak N, Haque M. A Systematic Review of Knowledge, Attitude and Practice on Adverse Drug Reactions and Pharmacovigilance among Doctor. J Appl Pharm Sci. 2014;4:117-27.

11. Varallo FR, de Oliveira Paim Guimarães S, Rodrigues Abjaude SA, de Carvalho Mastroianni P. Causes for the underreporting of adverse drug events by health professionals: a systematic review. Rev Esc Enferm USP. 2014;48(4):739-47.

12. Shaw D, Graeme L, Pierre D, Elizabeth W, Kelvin C. Pharmacovigilance of herbal medicine. J Ethnopharmacol. 2012;140(3):513-8.

13. World Health Organization. Pharmacovigilance for traditional medicne. Why and how? ; 2017.

14. Rajesh B, Dharani Devangi R, Anjum W. Assessment of knowledge, attitude, and practice of pharmacovigilance among doctors practicing alternative systems of medicine in Southern India: A questionnaire-based study. Natl J Physiol Pharm Pharmacol. 2017;7:1.

15. Bhanu Prakash G, Subash KR, Vijaya Chandra Reddy K, Sujith Kumar DS, Jyothi Prasad K, Umamaheswara Rao K. Knowledge, attitude, and practice of pharmacovigilance among Ayurvedic practitioners: A questionnaire survey in Andhra Pradesh, India. Natl J Physiol Pharm Pharmacol. 2016;6(5):475-9.

16. Dorji C, Tragulpiankit P, Riewpaiboon A, Tobgay T. Knowledge of adverse drug reaction reporting among healthcare professionals in Bhutan: A cross-sectional survey. Drug Saf. 2016;39(12):1239-50.

17. Daniel WW, Cross CL. Biostatistics: A Foundation for analysis in the health sciences: $10^{\text {th }}$ ed. New York. John Wiley \& Sons; 2013.

18. World Health Organization. Safety monitoring of medicinal products: Guidelines for setting up and running a pharmacovigilance centre. Uppsala, Sweden: the Uppsala Monitoring Centre(the UMC), WHO Collaborating Centre for International Drug Monitoring; 2000.

19. Awodele O, Akinyede A, Adeyemi OA, Awodele DF. Pharmacovigilance amongst doctors in private hospitals in Lagos, West Senatorial District, Nigeria. Int J Risk Saf Med. 2011;23(4):217-26.

20. Iffat W, Shakeel S, Rahim N, Anjum F, Neesar S, Ghayas S. Pakistani physicians' knowledge and attitude towards reporting adverse drug reactions. Afr J Pharm Pharmacol. 2014;14:379-85.

21. Walji R, Boon H, Barnes J, Austin Z, Welsh S, Baker GR. Consumers of natural health products: Natural-born pharmacovigilantes? BMC Complement Altern Med. 2010;10 